\title{
材料表面・界面の構造を明らかにする新しい物理解析技術
}

\author{
橋本 哲 ${ }^{\mathrm{a}}$, 櫻 田 委 大 $^{\mathrm{a}}$ \\ a JFE テクノリサーチ(株) ソリューション本部(川崎)ナノ材料評価センター \\ （７210-0855＼cjkstart神奈川県川崎市川崎区南渡田町 1-1）
}

\section{Advanced Microbeam Analysis for Characterizing Structure of Surface and Interface for Various Material}

\section{Satoshi HASHIMOTO ${ }^{\text {a }}$ and Tsuguo SAKURADA ${ }^{\text {a }}$}

${ }^{a}$ Solution Division(Kawasaki), Nano-scale Characterization Center, JFE Techno-Research Corporation(1-1, Minamiwatarida, Kawasaki-ku, Kawasaki-shi, Kanagawa 210-0855)

Keywords : Surface Analysis, Micro Beam Analysis, Scanning Electron Microscopy, Transmission Electron Microscopy

\section{1. はじめに}

XPS, AES, SIMS などの表面分析法, TEM や SEM など の電子顕微鏡法は表面処理・薄膜材料の微細構造を調べるた め, 広く用いられている。これら技術は, 先駆的な研究に始 まり, 安定した装置開発と材料に合わせた分析法の研究によ り，実用的な分析技術になった。例えば，XPSの原理であ る光電効果は Einstein により 1905 年に予見され ${ }^{1)}$, Siegbahn らにより元素の化学状態に決定に応用できることが 1957 年 に示された ${ }^{2)}$ 。これらノーベル賞が与えられた先駆的研究以 降, 分析手法の継続的研究により, 現在ではXPS は実用的 な分析技術となっている。本解説では, 先駆的な研究の紹介 でなく，材料開発の現場において行われる商用装置を用いた 実用的な分析の現状について述べる。

ここで実用的な分析とは, 要求される性能を発揮する材料 を開発し製造する現場での分析を意味している。例えば，自 動車用防錆鋼板として, 冬季に道路に散布される融雪塩が存 在する腐食性の高い環境においても自動車の安全走行を確保 するため, 80 年代初頭に自動車車体の防錆管理目標として, カナダコードやノルディックコードなどが提示され，車体構 造, 塗装, 化成処理, 表面処理鋼板の開発が行われた。耐食 性だけでなく, 溶接性, 加工性, 塗装性などの性能を兼ね備 えていることが必須である表面処理鋼板の開発において，こ の間で大きく進歩した表面分析・電子顕微鏡観察による構造 解析は重要な役割を果たした ${ }^{3), 4)}$ 。表面処理鋼板を含めた鉄 鋼材料, ガラスや製紙, 高分子材料, セラミックスなどの素 材, LSI などの半導体, MEMS, 磁性記録など各種機能部品, これらを総合的に利用する重工・重電, 自動車など, 様々な 産業分野で使われる表面処理・薄膜材料の設計・製造ニーズ に対して適切な分析法が構築され, 多くの材料, 部品の進歩 を支えてきた ${ }^{5) ~}$ 。

本解説では, 1960 年代以降実用的に使われている表面・
界面の解析技術，すわわち，薄膜 - 表面処理の組成や化学状 態の深さ方向分布などを解析できる表面分析法や電子顕微鏡 法について概観した後, 最近の進歩について述べる。

\section{2000 年までの表面・界面解析}

\section{1 表面・界面解析技術の進展}

個々の材料に合わせた分析技術の蓄積や試料調整法も進展 とともに，各手法での定量法に必要な物理量(電子の弾性 · 非弾性散乱平均自由行程 ${ }^{8), 9)}$ や背面散乱効果 ${ }^{10)}$, 特性 X 線の 発生関数 ${ }^{11)}$ など)の蓄積, 相対感度因子の理解, 標準物質の 作製・選択などの分析法の構築が行われた。

微小部の表面定量分析用の EPMA は 60 年代に, 深さ方向 分析や化学状態の解析に使われる表面分析装置(AES, XPS, SIMS) は 75 年代以降に, それぞれ商用機が販売された。こ れら装置も 80 年代から 90 年代にかけて PC 化するなど大き く進歩し, 使いやすいものとなった。その後 90 年代に, 微 小で高感度な分析ニーズに対応して, 電界放出電子源やイオ ン源などの照射系, 電子・イオン光学系, 検出系におけるマ ルチチャンネル検出など装置開発が進んだ結果, AES の分 析領域は $100 \mu \mathrm{m}$ から数 $10 \mathrm{~nm}$ に, XPS では $\mathrm{cm}$ から $100 \mu \mathrm{m}$ に, EPMA では数 $\mu \mathrm{m}$ から $100 \mathrm{~nm}$ の技術に進歩した。化学 状態分析が可能な XPS も単色化 X 線源の採用により, エネ ルギー分解能が向上し詳細な状態決定も可能になった。微量 分析の SIMS の感度は約二桁向上したことに加えて, TOF (Time of Flight) -SIMS の開発により有機物の状態分析も可能 となった。

電子顕微鏡では SEM は 60 年代に商用機が使われるよう なり, 微細な表面組織, 断面構造の観察が可能となった。安 定した電界放出型電子銃の開発により, 一桁以上分解能が向 上し，ビーム径として $1 \mathrm{~nm}$ 程度が得られている。ただし， バルク試料のナノレベルの解析が可能な TEM は試料作製の 困難さから, TEM は FIB が 90 年前半に実用化されるまで, 

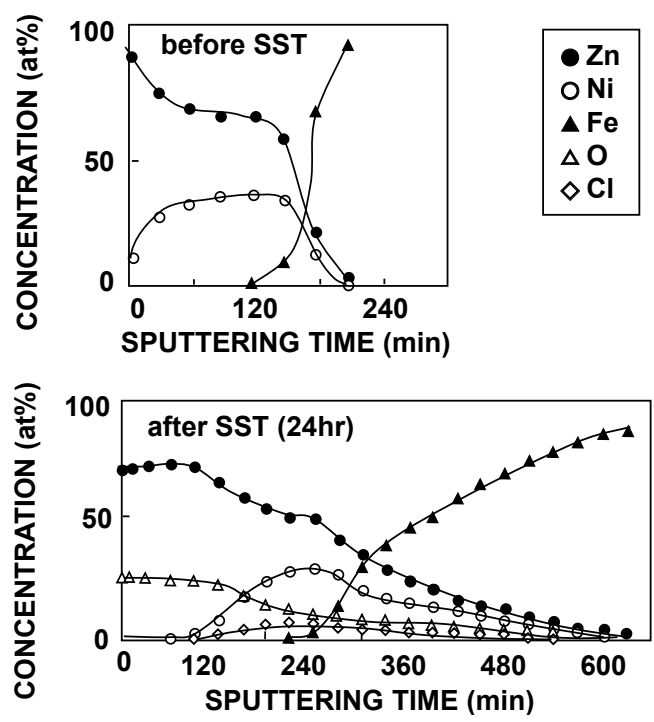

図1 $\mathrm{SST}$ 前後の $\mathrm{ZnNi}$ 合金電気めっき鋼板の $\mathrm{AES}$ 深さ方向分析 ${ }^{12)}$

皮膜断面の解析例は少なかった。

この時代の材料の分析例として, 腐食前後での $\mathrm{ZnNi}$ 合金 電気めっき皮膜解析結果を図 1 に示す ${ }^{12)}$ 。この結果から, 腐食生成物の表層は $\mathrm{Zn}$ の酸化物 (水酸化物も含む)であり, その内層に $\mathrm{Zn}, \mathrm{Ni}, \mathrm{Cl} ， \mathrm{O}$ からなる層が存在するとしている。 さらに, AES マッピングと XRD, XPS の結果と組み合わせ, 内層で絶縁性の $\mathrm{ZnCl}_{2} .4 \mathrm{Zn}(\mathrm{OH})_{2}$ が, 微細な $\mathrm{Zn}-\mathrm{Ni}$ 合金結晶 粒を取り囲むことにより腐食反応が抑制され，電気 Zn-Ni 合 金めっきは，高い耐食性を示すものと推定された ${ }^{12)}$ 。

\section{2 標準化}

現在広く使われる表面分析技術や電子顕微鏡技術も, 80 年代初頭までは，機関間でのトレーサビリティがあるかどう かは不明であった。状態分析, 元素分析において重要な分光 スペクトルのエネルギー軸, 定量分析に打ける強度軸, 深さ 方向に扔ける染さ軸, 画像に扔ける倍率や分解能など, 重要 なパラメータが異なるこれら手法を用いて分析を実施する分 析機関間で比較できるものかを明らかにするラウンドロビン

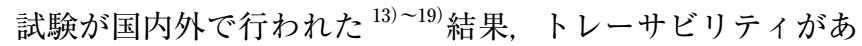
ること，またそのための分析法や装置較正法などが明らかと なった。これらの結果に基づき, 規格(ISO や JIS)が作られ ている ${ }^{20)}$

\section{2000 年以降の新技術：極低加速電圧 SEM を用い た材料極表面の解析}

\section{1 極低加速電圧での電子の振る舞いと特徵的な SEM 像}

SEM は細く絞った電子を試料に照射し, 表面から放出さ れる二次電子 (真の二次電子, 反射電子(弾性散乱電子と非弾 性散乱電子の両方を含む)など）用いた顕微鏡法である。 2002 年に, $100 \mathrm{~V}$ まで加速電圧を低くできる ULV-SEM (Ultra Low Voltage SEM) が国内で販売されるようになり，SEM 技 術は大きく変わった。ULV-SEM 技術は, 1) 電子の侵入深さ を小さくできナノレベルの材料極表面の観察ができること,

2)加速条件を制御することで帯電を防いで高分子材料やセラ ミックスなどの絶縁物でも試料前処理をしない観察ができる
こと 3) 表面形状以外の情報(表面形状，組成，化学状態，結 晶方位)が得られるなどの特徵がある ${ }^{21) ~ 23) 。 ~}$

加速電圧に対する SEM 観察の情報深さを図 2 に示した。 情報深さを, 電子の非弾性散乱平均自由行程 ${ }^{7}$ の 3 倍, すな わち入射した電子の約 $95 \%$ が減衰する長さとした。一般に SEM は表面に敏感とされているが，通常の高加速電圧(典型 的には 10 から $30 \mathrm{kV}$ 程度)に扔ける二次電子像では, 試料中 に数 $10 \mathrm{~nm}$ 以上拡散した入射電子と反射電子に上り励起さ れるため, 表面から数 $10 \mathrm{~nm}$ の平均構造を観察している。 $2 \mathrm{kV}$ 以下まで加速電圧を小さくすると, 情報深さが数 $\mathrm{nm}$ 以 下になり, Ni めっき表面のめっき残椬 ${ }^{24)}$, 冷延鋼鈑上の自 然酸化膜 ${ }^{22)}$ や Si ウエ八上に付着した有機系污れ ${ }^{23)}$ などの材 料最表面の構造や超微粒子が観察できる。

ULV-SEM (Carl Zeiss 社製 Ultra55 または 1530)を用いた観 察例を以下に示す。図 3 に加速電圧を変えて観察した Si ウ

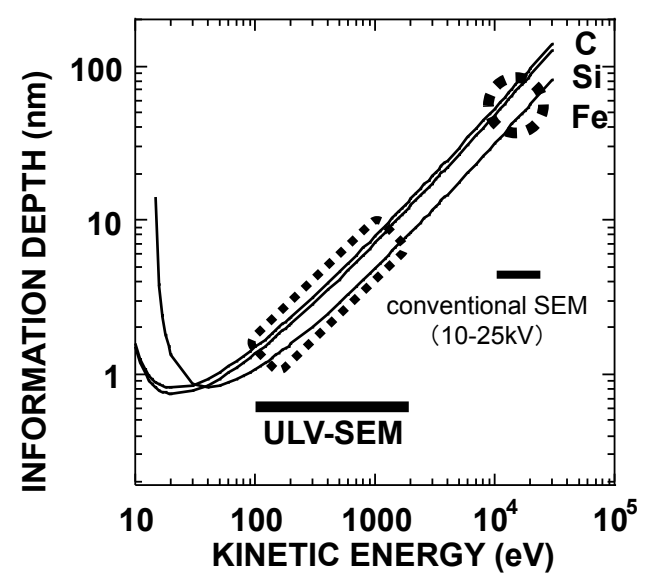

図 2 加速電圧による電子の情報深さ Tamura らによる電子の非弾性散乱平均自 由行程 ${ }^{8)}$ の 3 倍の值で示した。試料中で 平均自由行程の 3 倍の距離を通過すると, 約 $95 \%$ の電子が吸収される。

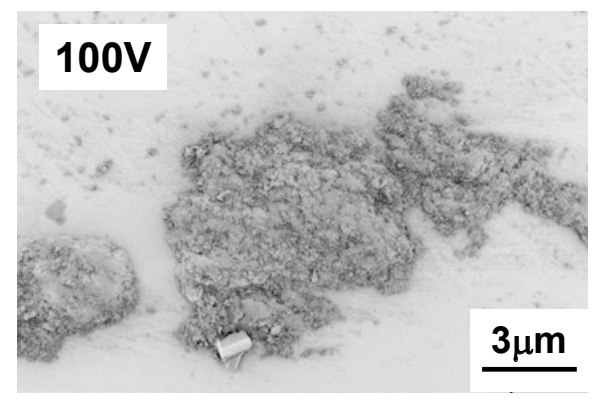

$15 k V$

図 $315 \mathrm{kV}$ と $100 \mathrm{~V}$ の加速電圧で観察した $\mathrm{Si}$ ウエハ上の有機物系污れの SEM 像 ${ }^{23)}$ 
エハ上の有機物系の污れを示す ${ }^{23)}$ 。従来の SEM で用いられ ている高加速電圧 $(15 \mathrm{kV})$ で観察すると, 均一な暗いコント

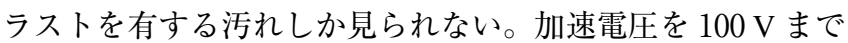
低くすることにより，この污れは一様ではなく，小さな粒の 集合体であることがわかる。さらに，中央の大きな污れの周 辺に, $0.1 \mu \mathrm{m}$ 程度の小さな粒子が広く存在していることも 観察される。高加速電圧の場合は, 電子の平均自由行程が大 きく，入射電子が最表面の污れを貫通して Si ウエハに達す るため, 二次電子の発生がほとんど $\mathrm{Si}$ ウエハからであるの に対し, 極低加速電圧では平均自由行程が小さくなり, 最表 面の污れが観察できたものと考えられる。

電子の検出器を選択することにより, 通常の二次電子像に 見られる表面形状以外の情報も可視化できる。図 4 に表面に 腐食生成物がわずかに発生した冷延鋼板の表面観察結果を示 す。電子の運動エネルギーの選択性の少ないET 検出器を用 いて観察した表面形状強調像では，平滑な鋼板上に腐食生成 物が形成している様子が観察できる。一方，20 V 以下程度 の電子が主に検出される環状インレンズ検出器を用いた SEM 像 (化学状態強調像) では, 腐食生成物の部分で暗く,
鋼板が明るいコントラストが得られ, 表面形状より物質の分 布の方が観察できる。EDX マッピングにより，この化学状 態強調像で暗いコントラストの部分が酸化物(水酸化物, 才 キシ水酸化物を含む)であることが確認できた。反射電子に よる組成コントラストによる組成分布の観察も行われている が, この系では, 化学状態強調像のほうが, 物質の違いを表 していることがわかる。

\section{2 低加速電圧励起 EDX による微細構造の分析}

SEM で観察した部分を定性・定量分析，マッピングする ため, EDX 分析が広く用いられている。高加速電圧で励起 した場合の EDX の空間分解能は数 $\mu \mathrm{m}$ であるのに対し，加 速電圧を小さくすることで一桁以上小さい $30 \mathrm{~nm}$ 程度の分 解能が得られる ${ }^{25), 26)}$ 。

ULV-SEM に取り付けた EDS 分光器 (サーモフィッシャー サイエンティフィック社製, NSS300)を用い, Si ウエハ上に 形成した W $(12 \mathrm{~nm}) / \mathrm{Cr}(35 \mathrm{~nm})$ 金属多層膜/ $\mathrm{TaOx}$ 皮膜断面 の EDX 分析結果を図 5 に示す ${ }^{26)}$ 。加速電圧を沉用的に用い られる $10 \sim 20 \mathrm{kV}$ の内, $10 \mathrm{kV}$ とした場合, $12 \mathrm{~nm}$ の $\mathrm{W}$ 層 と $35 \mathrm{~nm}$ の $\mathrm{Cr}$ 層とが分離できず，1つの層のように測定さ
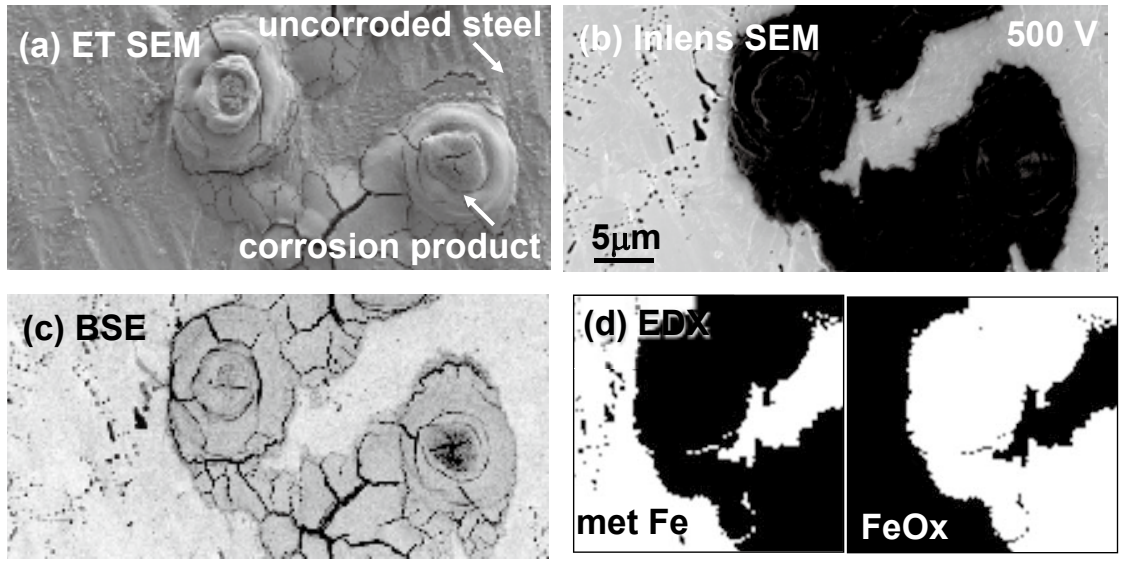

図4＼cjkstart初期さびの発生した冷延鋼板表面の観察結果

(a) 表面状態強調像：ET 検出器, (b) 化学状態強調像：環状インレンズ検出器,

(c) 反射電子像，(d) EDX マッピング：多変量解析により, $\mathrm{Fe}$ と $\mathrm{FeOx}$ 成分に分離。

(a) after peak separation

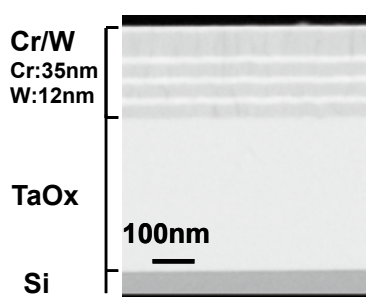

BSE

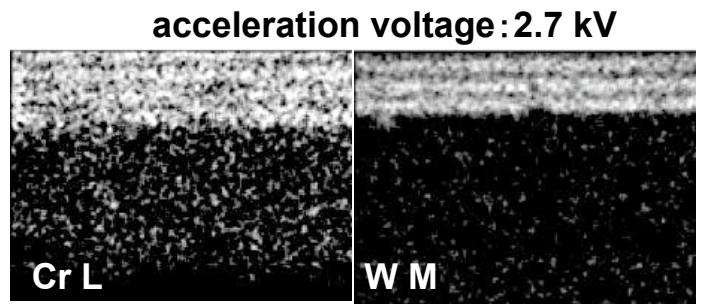

acceleration voltage : $10 \mathrm{kV}$

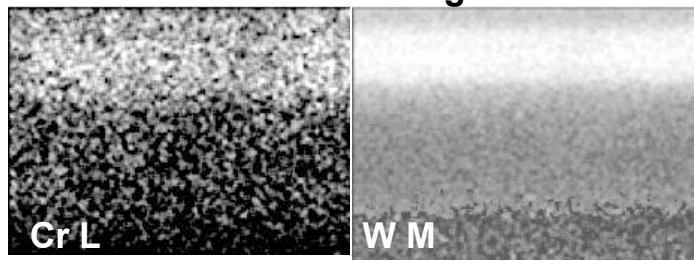

(b) as measured acceleration voltage: $2.7 \mathrm{kV}$
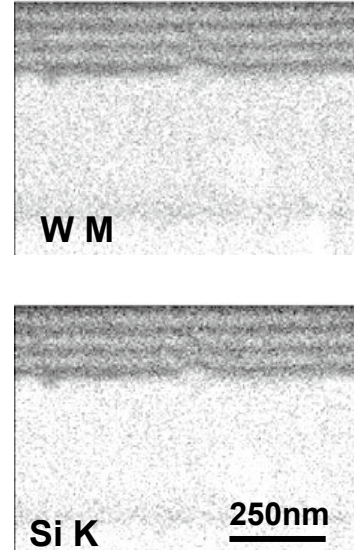

図 $5 \mathrm{Si}$ ウエハ上に形成した $\mathrm{W}(12 \mathrm{~nm}) / \mathrm{Cr}(35 \mathrm{~nm})$ 金属多層膜断面の EDX マッピング ${ }^{26)}$

(a) ピーク分離したもの：加速電圧 $2.7 \mathrm{kV}, 10 \mathrm{kV} ，$ (b) 測定ままのピーク強度マッピング： $\mathrm{Si} \mathrm{K}, \mathrm{W} \mathrm{M}$ 
れているのに対し, 加速電圧を $2.7 \mathrm{kV}$ と低くすることにより， $\mathrm{W}$ 層と $\mathrm{Cr}$ 層とを明瞭に分析できることがわかる。

ここで, 低加速電圧励起では結合エネルギーが大きい内殼 電子を励起できないいため, 低運動エネルギーのピーク $(\mathrm{O}$ : $\mathrm{K}, \mathrm{Si}: \mathrm{K}, \mathrm{Cr}: \mathrm{L}, \mathrm{W}: \mathrm{M}, \mathrm{Ta}: \mathrm{M})$ を用いた。 EDS 分光器 のエネルギー分解能が低いため特性 X 線スペクトルに対し, 標準スペクトルを用いたピーク分離を行った結果, W と Si, $\mathrm{Ta}$ との分布が，また $\mathrm{Cr}$ と $\mathrm{O}$ との分布が分離できている。

低加速電圧励起で高空間分解能 EDX 分析が可能となった 要因は，1)低エネルギーのため電子の拡散が小さいこと，2） 低加速電圧でもビーム径が充分小さいこと，3）ビームドリフ ト・試料ドリフトを押さえるためSEM 画像を用いた移動補 正行ったこと，4）重なる特性 X 線スペクトルのピーク分離 を行ったことによるものと考えられる。

\section{2000 年以降の新技術：Cs 補正 STEM 用いた 原子スケールの構造解析}

\section{1 表面処理・薄膜に対する TEM 技術の適応}

90 年代後半に, 特定の位置を狙って薄い試料を作製可能 な質の良い FIB 装置が商用化され，薄膜・表面処理の断面 構造を解析できるようになった ${ }^{27)}$ 。加えて, 球面収差 $(\mathrm{Cs})$ を小さくできる補正レンズが開発され，2005 年に従来の限 界を越えた空間分解能が得られる Cs 補正 STEM が商用化さ れた ${ }^{28)}$ 。Cs 補正 STEMに搭載した EDXや EELS (Electron Energy Loss Spectroscopy : 電子エネルギー損失分光法)を用 いることで, ナノスケールでの EDX 分析で元素の定性分析・ 定量分析・分布分析が可能になり, EELS 分析でナノスケー ルでの軽元素の検出や, 化学状態評価も可能となった ${ }^{29), 32)}$ 。

\section{2 Cs 補正 STEM を用いた原子スケールでの材料の観察}

Cs 補正 STEM (Tiatn80-300：FEI 製，ARM200F：日本電子 製)を用いた，微細領域の観察・解析を行った例を以下に示す。 図6に, Cs 補正 STEMによる GaAs/AlGaAs 超格子断面の HAADF-STEM (High-angle Annular Dark Field Scanning TEM) 像を示す。低倍の像では $\mathrm{GaAs}$ 層が明るく $\mathrm{AlGaAs}$ 層が暗く 観察されている。原子分解能の像では, 原子番号が近い Ga-As 最近接原子対の両原子コラムの強度はほぼ同じである のに対し， $\mathrm{Al}(\mathrm{Ga})$-As では強度の非対称が見られている。 これは, 散乱能が, 電子数に依存する局所のポテンシャルに

\section{EDX line profile}

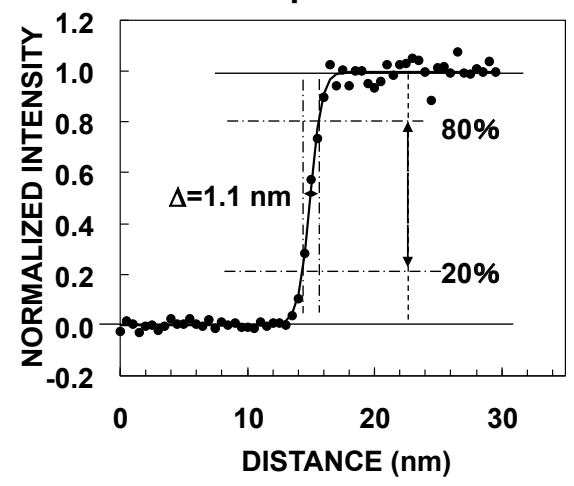

関連しているため, $\mathrm{Ga}$ コラムが $\mathrm{Al}$ コラムより明るく観察さ れている。このように, 並進対称性を反映する HR-TEM 像 と異なり, STEM 像では個々の原子コラムを直接見分けるこ とができる。

このような原子レベルの観察技術は大変重要ではあるもの の，必ずしも原子 1 個 1 個のプロセス制御がされてはいない 実用材料の材料物性に対する構造の役割を理解するためには, 局所の原子配列観察よりもナノスケールの分析が重要と思わ れる。図 7 に, GaAs/AlGaAs 超格子断面の Cs 補正 STEM に よるEDX および EELS 線分析結果 ${ }^{32)}$ を示す。ここでは, 空 間分解能を EDX または EELS 強度が $20 〜 80 \%$ となる界面 幅と定義した。EDXの場合は $1.1 \mathrm{~nm}$ であり, EELSでは $1.5 \mathrm{~nm}$ であった。Cs 補正 STEM-EDX あるいは EELS 分析で は, 原子スケールのマッピングが行われており ${ }^{33)}$, 特定サ イトの占有率の測定も可能になっている。ここに示した分析 は一見分解能が低いように見える。しかし, 原子マッピング は対称性が高い完全結晶において達成されている。実際の TEM 用試料の厚さは数 $10 \mathrm{~nm}$ 程度であるのに対し, 表面処 理材料における界面の粗さはビーム径 $(0.1 \mathrm{~nm}$ 程度 $)$ より きく, 得られる分析結果は, 試料厚さ方向に平均化され, 分 解能は大きくなってしまう。

材料の最表面を分析する場合，簡便で定量性も確保できる XPS やAES などの表面分析の方が適しているが, 深い位置 にある数 nm の界面に対してはスパッタリングできないため, 分析が困難となる。Cs 補正 STEM-EDX/EELS 分析はこのよ うな深い位置にある界面においても適応可能である。図 8 に,

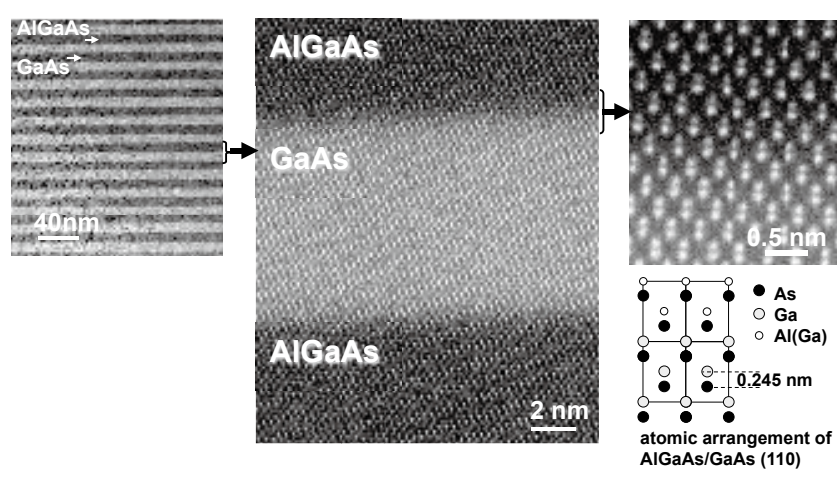

図 $6 \mathrm{GaAs} / \mathrm{AlGaAs}$ 超格子薄膜の HAADF 像

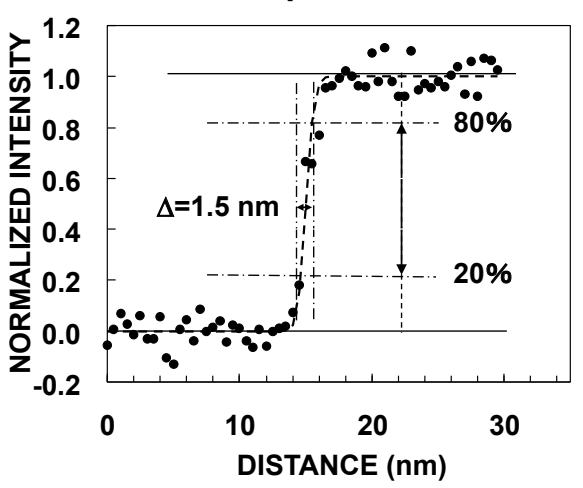

图 $7 \mathrm{GaAs} / \mathrm{AlGaAs}$ 超格子薄膜の Cs 補正 STEM EDX およよ゙ EELS 線分析 ${ }^{32}$ 


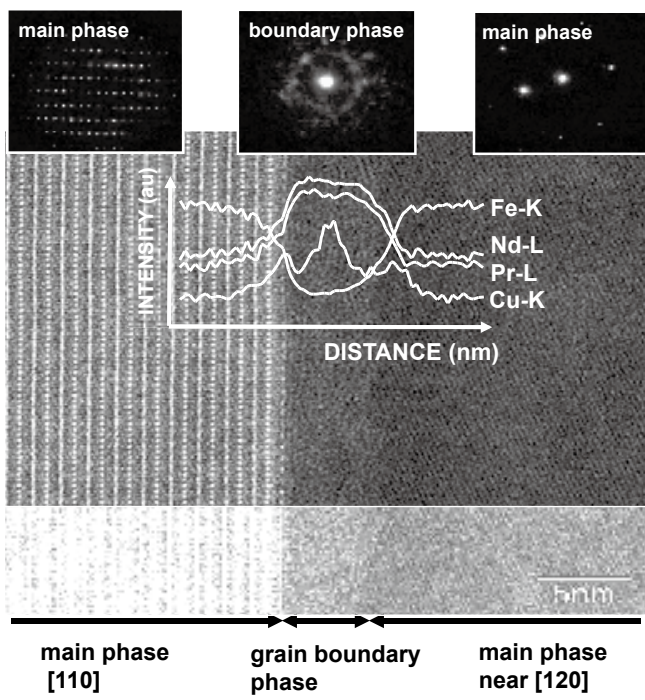

图 8 ネオジム磁石結晶粒界面の Cs 補正 STEM を用 いた解析結果 ${ }^{32)}$

HAADF 像中に, 界面を挟んで行った EDX 線分析結果を示し，および主相および界面で の電子回折図形を上方に示す。HAADF 像の 下方にはコントラストを変えたものを示す。

ネオジム磁石結晶粒界の観察結果を示す ${ }^{32)}$ 。左右の結晶粒 のコントラストが大きく異なるので，コントラストを変えた HAADF 像も下方に示した。HAADF 像に打ける左側の結晶 粒(主相) は [110］の方位であり，原子コラムが観察できて いる。右は [120］に近いが対称軸入射でないため，原子コ ラムまでは見えていない。その結晶粒界面に, 数 $\mathrm{nm}$ 程度の 主相と異なるアモルファスあるいは微結晶の界面層が見られ る。界面層を挟んで EDX 線分析を行った結果，その界面層 に $\mathrm{Nd}, \mathrm{Pr}$ の希土類元素が偏析していること, $\mathrm{Cu}$ がこれらと 異なる分布で偏析していることが確認された。

\section{5. 今後の表面・界面解析技術}

目覚しい発展を遂げた電子顕微鏡技術では, 観察範囲が数 〜十数 $\mu \mathrm{m}$ の一断面に限られている。一般の表面处理・薄膜 では深さ方向の構造が $\mathrm{nm}$ レベルであっても，面内には大き な摇らぎがあることが多く，一ヶ所の断面観察結果がその材 料の代表的な構造を示しているとは限らない。最近使われる ようになってきた，FIB と SEM とを組み合わせた $3 \mathrm{D}$ 解析 技術や TEM の 3D トモグラフィ技術は，この代表性を確保 する方法の一つと考えられる。

また，図１に示したようなXPS や AES による広い面積の 深さ方向分析は，代表性を保って扮り，重要な技術である。 条件ごとで決まる分解能さえ理解しておくと，界面の広がり から, 元素の拡散や反応を解析できるし, 膜厚や組成のムラ も考察できる。図1で腐食したものの結果で界面がだれてい るのは場所により腐食生成物の厚さが異なることを意味して いるものと思われる。ただし，イオンスパッタリングによっ て生じる物質の変化 ${ }^{15)}$ や選択スパッ夕による組成の変化 ${ }^{34)}$ は避けられない。この分析による变化を避ける方法として,

HAXPES (HArd X-ray PhotoEmission Spectroscopy：硬 X 線光 電子分光法)を用いた埋もれた界面の分析 ${ }^{35}$ が，代表性を確
保する別の方法となる可能性がある。

極低加速電圧励起の SEM 像のコントラストは単純でな 〈21) 24),36),37)，物理的解釈は十分でない。例えば，反射電子 に関しては, 高加速電圧の様な系の平均電子番号に比例した コントラスト $(\mathrm{Z}$ コントラスト)とは異なる振る舞いをしてい る $^{37), 38)}$ など，二次電子像，反射電子像の解釈に関する研究 が必要である。

従来の分析結果は, 組織形態, 定性, 定量など分析した結 果そのものであったが，工夫して計測した結果にデー夕処理 することで材料物性を直接表現する物性量を得ることも重要 になる。例えば，EELSに現れるバンド間遷移から求めた誘 電関数による LowK 皮膜の評価 ${ }^{39}$ や磁性のスピンや磁気 モーメントの示す磁気円二色性の評価 ${ }^{40)}$, TEM トモグラフィ を用いたポテンシャル分布評価 ${ }^{41)}$ な゙はその可能性を示す ものと考えられる。

\section{6.おわりに}

表面処理・薄膜材料の微細構造を調べるため広く用いられ ている表面分析技術・電子顕微鏡法など，表面・界面の分析 技術は，商用 SEM 装置が使えるようになって以降のこの 50 年で大きく進歩し，鉄鋼，半導体など多くの材料開発に貢献 してきた。本稿では，表面・界面の分析技術の最新の状況を 概観した。

これら分析技術は新材料・プロセスの研究・開発, トラブ ルシューティング，生産管理など異なる場面で使われている ものの, 万能なものではなく, 材料の構造のある側面を明ら かにするものである。どのような基本構造が制御したい材料 物性を支配するかを考え，その構造に合わせた最適な分析法 を採用することで，適切な結果が得られる。

分析には，異なる 3 つの開発の立場が，すなわち，材料開 発, 分析手法開発, 装置開発とがある。この順で分析ニーズ が発生し，これに応える分析シーズはその逆に発信される。 互いのニーズ・シーズ技術の共有化をした上で，それぞれが その技術を高度化することが必要である。分析手法の立場で は，材料開発者が制御したい物性に合わせて，最適な分析手 法を選択・構築するし，このために必要な機能を分析装置の 開発者に提案することになる。今後も，これまでのように表 面・界面分析に倸わる技術者が，それぞれの立場での研究・ 開発を進めることで, 薄膜・表面処理材料の発展に寄与でき るものと信じている。

(Received August 27, 2015)

\section{文献}

1 ) A. Einstein ; Annalen der Physik, 17, 132 (1905).

2 ) C. Nordling, E. Sokolowski, K. Siegbahn ; Phys. Rev., 105, 1676 (1957)

3 ) 橋本 哲; 表面科学, 22,128 (2001)

4 ) 名越正泰; 第 $219 \cdot 220$ 回西山記念講座資料, p.161 (2014).

5 ）笹川 薰; 表面科学, 32,254 (2011)

6 ) 中村 誠; 表面科学, 32,246 (2011)

7 ) 日本学術振興会 マイクロビームアナリシス第141委員会編； マ イクロビームアナリシス・ハンドブック(オーム社, 2014).

8 ) S. Tanuma, C. J. Powell, D. R. Penn ; Surf. Interface Anal., 21, 165 
(1994).

9 ) C. J. Powell, A. Jablonski ; Surf. Interface Anal., 33, 211 (2002).

10) Ding Ze Jun, R. Shimizu, S. Ichimura ; Surf. Interface Anal., 10, 253 (1987).

11）西尾満章; J. Surf. Anal., 20, 111 (2013).

12）福田安生, 土谷康夫, 寺坂正二, 中岡一秀, 原 富啓; 鉄と鋼, 72, 1782 (1986).

13）大坪孝至, 広川吉之助, 福田安生, 大橋善治, 薄木智亮, 源内規夫, 石田英明, 吉田鎮雄, 関本靖裕, 鈴木堅市; 鉄と鋼, 73, 259 (1987).

14）大坪孝至, 広川吉之助, 福田安生, 大橋善治, 薄木智亮, 源内規夫, 石田英明, 吉田鎮雄, 関本靖裕, 鈴木堅市; 鉄と鋼, 73, 437 (1987).

15）橋本 哲, 広川吉之助, 福田安生, 鈴木堅市, 鈴木敏子, 薄木智亮, 源内規夫, 吉田鎮男, 甲田 満, 瀬崎博史, 堀江 浩, 田中彰博, 大 坪孝至 ; 鉄と鋼, 78, 149 (1992).

16）薄木智亮, 広川吉之助, 福田安生, 鈴木堅市, 橋本 哲, 鈴木敏子, 源内規夫, 吉田鎮男, 甲田 満, 瀬崎博史, 堀江 浩, 田中彰博, 大 坪孝至 ; 鉄と鋼, 78, 158 (1991)

17) C. J. Powell, N. E. Erickson, T.E. Madey; J. Electron Spectrosc. Relat. Phenom., 25, 87 (1982)

18）表面化学分析作業部会 ; J. of Surf. Anal., 8, 269 (2002).

19) M. P. Seah ; Surf. Interface Anal., 20, 243 (1993).

20）一村信吾, 田沼繁夫, 田中幸基 ; マイクロビームアナリシス・八 ンドブック, 日本学術振興会 マイクロビームアナリシス第141委 員会編, p .605 (オーム社, 2014)

21）清水健一, 立花繁昭, H.Yaksch, 幅崎浩樹; 工業材料, 52, 70 (2004).

22）佐藤 馨, 名越正泰, 河野崇史, 本間芳和; 応用物理, 73,1328 (2004).

23）橋本 哲; 日本信頼性学会誌, 28, 155 (2006).

24）土谷康夫, 立花繁明, 花田 剛, 橋本 哲, 櫻田委大 ; 2006年度材 料技術研究協会討論会 (2006).
25) T. Sakurada, S. Hashimoto, Y. Tsuchiya, S. Tachibana, M. Suzuki, K. Shimizu ; J. Surf. Anal., 12, 118 (2005).

26) S. Hashimoto, Sakurada, M. Suzuki ; J. Surf. Anal., 14, 428 (2008).

27）洪 文恵, 加藤丈晴, 坂 公恭; 鉄と鋼, 83, 311 (1997).

28）田中信夫; 顕微鏡, 46, 175 (2011).

29) S. D. Findlay, N. Shibata, H. Sawada, E. Okunishi, Y. Kondo, T. Yamamoto, Y. Ikuhara; Appl. Phys. Lett., 95, 191913 (2009).

30) E. Hamada, K. Yamada, M. Nagoshi, N. Makiishi, K. Sato, T. Ishii, K. Fukuda, S. Ishikawa, T. Ujiro ; Corr. Sci., 52, 3851 (2001).

31）猪瀬 明, 橋本 哲, 小形健二, 前田千寿子, 矢野裕司; 応用物理 学会, 先進パワー半導体研究会第22回講演会, L16 (2013).

32）橋本 哲, 小形健二, 池本 祥, 北原保子, 猪瀬 明, 前田千寿子; 希土類学会 第30回希土類討論会, 2A-11 (2013).

33）柴田直哉, フィンドレイ・スコット, 幾原雄一; 顕微鏡, 46,55 (2011).

34) G. Betz ; Surf. Sci., 92, 283 (1980).

35) N. Hoshiya, N. Isomura, M. Shimoda, H. Yoshikawa, Y. Yamashita, K. Iizuka, S. Tsukamoto, S. Shuto, M. Arisawa ; Chem Cat Chem., 1, 279 (2009).

36) R. Schmid, K. H. Gaukler, H. Seiler ; Scanning Electron Microscopy, p.501 (1983, SEM Inc, AMF OHare).

37) 櫻田委大, 橋本 哲, 前田千津子, 後藤敬典; 2009年日本表面科学 会講演大会, 159 (2009)

38）橋本 哲, 櫻田委大, 後藤敬典, 田沼繁夫 ; 日本顕微鏡学会 第71 回学術講演会, p.56 (2015).

39）阿南義弘, 高口雅成, 朝山匡一郎, 木本浩司, 松井良夫 ; 電子顕微 鏡, 44, 227 (2009).

40) P. Schattschneider, S. Rubino, C. Hébert, J. Rusz, J. Kuneš, P. Novák, E. Carlino, M. Fabrizioli, G. Panaccione, G. Rossi ; Nature, 441, 486 (2006)

41) W. D. Rau, P. Schwander, F. H. Baumann, W. Höppner, A. Ourmazd ; Phys. Rev.Lett., 82, 2614 (1999).

\section{補 遺}

本文では，一般的に使われるようになった分析手法の表記として略語だけを示したが，参考として，本解説で触れなかった技術 のものと合わせて，表 1 に示す。

表 1 各種表面技術・顕微鏡技術の名称 $(*$; 本文では触れていない分析技術)

\begin{tabular}{|c|c|c|c|}
\hline 分野 & 略称 & 英文名称 & 邦文名称 \\
\hline \multirow[t]{7}{*}{ 表面分析 } & AES & Auger Electron Spectroscopy & オージェ電子分光法 \\
\hline & XPS & X-ray Photoelectron Spectroscopy & X 線光電子分光法 \\
\hline & HAXPES & HArd X-ray PhotoEmission Spectroscopy & 高 X 線光電子分光法 \\
\hline & SIMS & Secondary Ion Mass Spectrometry & 二次イオン質量分析法 \\
\hline & TOF-SIMS & Time of Fright Secondary Ion Mass Spectrometry & 飛行時間型二次イオン質量分析法 \\
\hline & GDS* & Glow Discharge Spectroscopy & グロー放電発光分光法 \\
\hline & EPMA & Electron Probe MicroAnalysis & 電子線マイクロアナリシス \\
\hline \multirow[t]{10}{*}{ 顕微鏡法 } & SEM & Scanning Electron Microscopy & 走查電子顕微鏡法 \\
\hline & ULV-SEM & Ultra Low Voltage Scanning Electron Microscopy & 極低加速電圧走査電子顕微鏡法 \\
\hline & EDX & Energy Dispersive X-ray Spectroscopy & エネルギー分散型 X 線分光法 \\
\hline & EBSD* & Electron Backscatter Diffraction & 後方散乱電子回折法 \\
\hline & TEM & Transmission Electron Microscopy & 透過電子顕微鏡法 \\
\hline & STEM & Scanning Transmission Electron Microscopy & 走査透過電子顕微鏡法 \\
\hline & HAADF & High Angle Annular Dark Field & 高角度環状暗視野 \\
\hline & EELS & Electron Energy Loss Spectroscopy & 電子エネルギー損失分光法 \\
\hline & SPM* & Scanning Probe Microscopy & 走査プローブ顕微鏡法 \\
\hline & $\mathrm{AFM}^{*}$ & Atomic Force Microscopy & 原子間力顕微鏡法 \\
\hline
\end{tabular}

